\title{
Den billedlige vending
}

Alle impulserne fra medierne blev lagt ind $i$ mine drømmes kredsløb. Som et ekko. Som et billede i billedlig skikkelse.

Richard Rorty har karakteriseret filosofihistorien som en række 'vendinger', hvori "en række nye problemer dukker op, og de gamle begynder at fortone sig":

64 Forestillingen om, at den antikke og middelalderlige filosofi var optaget af ting, at filosofien i det 17. og frem til det 19. århundrede var optaget af ideer og samtidens oplyste filosofiske kredse af ord, rummer betydelig plausibilitet.

Den sidste fase af Rortys filosofihistorie er det, han kalder 'den sproglige vending', en udvikling med komplekse genklange inden for andre humanvidenskabelige discipliner. Lingvistik, semiotik, retorik og forskellige former for 'tekstualitet' er blevet lingua franca for de kritiske refleksioner over kunst, medier og kulturelle former. Samfundet er en tekst. Naturen og dens videnskabelige repræsentationer er 'diskurser'. Selv det ubevidste er struktureret som et sprog. ${ }^{\text {. }}$

Det er ikke specielt indlysende, hvordan disse forskydninger i den akademiske og intellektuelle diskurs hænger sammen indbyrdes, og da slet ikke hvad de har at gøre med hverdagslivet og dagligdagssproget. Men det står forholdsvis klart, at der er ved at ske en anden forskydning i filosoffernes samtaleemner, og at denne forskydning endnu en gang står i kompleks forbindelse til en anden transformation inden for andre humanvidenskabelige discipliner og i den kulturelle offentlighed. Denne forskydning vil jeg betegne som 'den billedlige vending'. Inden for angloamerikansk filosofi kan varianter af denne vending allerede spores i Charles Peirces semiotik og senere i Nelson Goodmans Languages of Art, som begge udforsker de konventioner og koder, der ligger til grund for ikke-sproglige symbolsystemer, og (hvad vigtigere er) ikke tager udgangspunkt i en antagelse om, at sprog er paradig- 
matisk for betydning. ${ }^{2}$ I europæisk sammenhæng vil man måske identificere den med fænomenologiens undersøgelse af forestillingsevnen og den visuelle erfaring eller med Derridas 'grammatologi', som de-centrerer den 'fonocentriske' sprogopfattelse ved at forskyde opmærksomheden over på skriftens synlige, materielle spor, eller med Frankfurterskolens analyser af modernitet, massekultur og visuelle medier eller med Michel Foucaults insisteren på en magt/viden-historie og -teori, som afdækker kløften mellem det diskursive og det 'synlige', det, der kan ses, og det, der kan siges, som den afgørende brudflade i modernitetens 'skopiske regimer'. ${ }^{3}$ Først og fremmest ville jeg placere den billedlige vendings filosofiske iscenesættelse i Ludwig Wittgensteins tænkning, især i det tilsyneladende paradoksale ved en filosofisk karriere, der begyndte med en 'billedteori' om betydning og sluttede med en art ikonoklasme, en kritik af billedsprog, der bragte ham til at forkaste sin tidligere privilegering af billedet og sige: "Et billede holder os fangen. Og vi kunne ikke komme ud af det, det lå nemlig i vort sprog, som bare synes at gentage det ubønhørligt for os." ${ }^{4}$ Rortys ihærdige bestræbelser på "helt og aldeles at fjerne den visuelle, og ikke mindst spejlingens, metafor fra vores tale"5 lyder som en genklang af Wittgensteins ikonofobi og sprogfilosofiens generelle ængstelighed omkring visuel repræsentation. Denne ængstelighed, dette behov for at forsvare 'vores tale' mod 'det visuelle', er et sikkert tegn, skulle jeg mene, på en umiddelbart forestående billedlig vending. ${ }^{6}$

Det skal selvfølgelig ikke forstås sådan, at alle disse forskellige konfrontationer med den visuelle repræsentation kan reduceres til en enkelt tese, eller at alle ængsteligheder omkring 'det visuelle' kan komme ud på ét. Rortys anliggende er at bringe filosofien ud over sin forgabelse i epistemologien og navnlig dens forblindelse af forestillingen om billedet som figuration af repræsentationel transparens og realisme. For ham er 'spejlet' den store fristelse for scientismen og positivismen. For Frankfurterskolen er det billedlige regime derimod forbundet med massemedierne og truslen om en fascistisk kultur. ${ }^{7}$ Den billedlige vending går altså ikke bare ud på, at vi har en stærk redegørelse for visuel repræsentation, der kan diktere kulturteoriens rammer og præmisser, men at billeder udgør et særligt foruroligende friktionsfelt, der gør sig gældende inden for en hel række forskellige åndsvidenskabelige undersøgelsesområder. Billedets status ligger i dag et sted mellem 'paradigme' og 'anomali' med Thomas Kuhns termer. Det fremstår i stigende grad som et helt centralt humanvidenskabeligt diskussionsemne ligesom tidligere sproget, dvs. som en slags model eller figur for andre ting (deriblandt figuration som sådan), som et uløst problem og måske ligefrem som genstanden for sin helt egen 'videnskab' - Erwin Panofskys 'ikonologi'. Det kan man lettest formulere på den måde, at vi - selv i denne tidsalder, der ofte karakteriseres som netop 'skuespillets' (Guy Debord) eller 'overvågningens' (Foucault) tidsalder, fordi den er gennemsyret af omsiggribende billeddannelse - faktisk ikke rigtig ved, hvad billeder er, hvordan de forholder sig til sproget, hvordan de påvirker beskuerne og verden, hvordan deres historie skal forstås, og hvad vi skal gøre med eller ved dem.

Studiet af bildende kunstarter har ikke været upåvirket af disse udviklinger, men det har heller ikke ligefrem været med i front. Især den angloamerikanske kunsthistorie har først lige fået øjnene op for implikationerne af den sproglige vending. 
Hvor franske forskere som Louis Martin og Hubert Damisch var banebrydende med lanceringen af en strukturalistisk kunsthistorie, da er anglo-amerikansk kunsthistorie vedblevet at fokusere på sociologiske spørgsmål (navnlig i form af mæcenatstudier) og sky al teori som pesten. ${ }^{8}$ Der skulle en overløber fra litteraturvidenskaben som Norman Bryson til, før man fik introduceret det sidste nye fra Frankrig og vækket kunsthistorien af sin dogmatiske tornerosesøvn. ${ }^{9}$

$\mathrm{Nu}$ hvor kunsthistorien er vågen og fuldt bevidst, i det mindste om den sproglige vending, hvad vil den så foretage sig? De lærde tidsskrifter bugner allerede af forudsigelige alternativer i form af opdagelser af, at de bildende kunstarter i virkeligheden er 'tegnsystemer' styret af 'konventioner', og at malerier, fotografier, skulpturelle objekter og arkitektoniske monumenter er fyldt med 'tekstualitet' og 'diskurser'. ${ }^{\text {Io }}$ Et mere interessant alternativ synes imidlertid at ligge i selve de bildende kunstarters modstand mod den sproglige vending. Hvis der vitterlig er ved at ske en billedlig vending i humanvidenskaberne, vil kunsthistorien meget vel kunne gå fra en teoretisk marginaliseret status til en helt central position i det intellektuelle landskab, fordi den i så fald skulle levere en redegørelse for sin egen primære teoretiske genstand - nemlig den visuelle repræsentation - som vil kunne bruges af andre humanvidenskabelige discipliner. Det vil helt klart ikke være nok blot at tage sig af mesterværkerne inden for den vestlige malerkunst. Der vil være behov for en bred, tværfaglig kritik, som inddrager parallelle bestræbelser så som filmvidenskabens lange kamp for at nå frem til en fyldestgørende balance mellem de sproglige og imagistiske modeller for filmkunsten og situere filmmediet $i$ en bredere visuel kulturkontekst.

Hvis man spørger sig selv, hvorfor der forekommer at være tale om en billedlig vending netop her i anden del af det 20. århundrede - en æra, der ellers ofte bliver karakteriseret som 'postmoderne' - vil man støde på et paradoks. På den ene side er det i helt overvældende grad indlysende, at videoteknologiens, kybernetikkens og den elektroniske reproduktions tidsalder har udviklet nye og hidtil uhørt potente former for visuel simulation og illusionisme. På den anden side har vi frygten for, at 'billedernes magt' vil ende med at knuse dem, der har skabt og manipuleret med

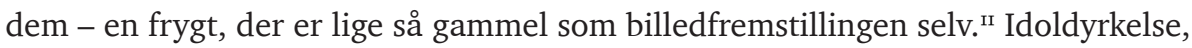
ikonoklasme, ikonofili og fetichisme er ikke specifikt 'postmoderne' fænomener. Det, der er specifikt for vores historiske situation, er derimod netop dette paradoks. Fantasien om en billedlig vending, om en fuldstændig billeddomineret kultur, er nu blevet en reel teknisk mulighed i global skala. Marshall McLuhans 'globale landsby' er i dag en - ikke særlig betryggende - kendsgerning. CNN har vist os, at en angivelig ganske årvågen og oplyst befolkning (for eksempel de amerikanske vælgere) kan sidde og følge med i massedestruktionen af en hel arabisk nation og ikke betragte det som stort andet end et spektakulært tv-melodrama, lige efter bogen med en simpel fortælling om det godes sejr over det onde, efterfulgt af en hurtig udviskning fra den offentlige hukommelse. Medierne havde imidlertid ikke kun vist, at de evnede at få en "blidere og mildere nation" [hvilket var, hvad George H. W. Bush stillede amerikanerne i udsigt ved sin nominering som Republikansk præsidentkandidat i 1988, o.a.] til at acceptere destruktionen af en sagesløs irakisk befolkning uden skyld eller anger. Endnu mere bemærkelsesværdigt var det, at de formåede at bruge 
den spektakulære visuelle fremstilling af den destruktion til at bortmane og udviske enhver skyld over eller erindring om en tidligere spektakulær krig. Som George H.W. Bush så rammende formulerede det: "Ånden efter Vietnam, der har hjemsøgt os så længe, er blevet begravet for altid i ørkensandet på Den Arabiske Halvø." Eller måske fik Dan Rather formuleret moralen mere træffende, da han sammenstillede arkivoptagelser af den sidste amerikanske helikopter, der flyver væk fra den amerikanske ambassade i Saigon, med live-optagelser af en helikopter, der lander på den amerikanske ambassade i Kuwait City: "Nu er der selvfølgelig grænser," sagde Rather, "for hvor meget et billede kan sige..."

Hvad end den billedlige vending er, kan der ikke være nogen tvivl om, at den ikke betegner en tilbagevenden til naive mimesis-, kopi- eller korrespondanceteorier om repræsentation eller en fornyet metafysik om billedligt 'nærvær'. Der er snarere tale om en postlingvistisk, postsemiotisk genopdagelse af billedet som et komplekst samspil mellem visualitet, apparatur, institutioner, diskurs, kroppe og figuralitet. Den er udtryk for en erkendelse af, at beskuelsen (synet, blikket, øjekastet, iagttagelsespraksisser, overvågning og visuel nydelse) måske udgør et lige så graverende problem som de forskellige former for læsning (dechifrering, afkodning, fortolkning osv.), og at visuel erfaring eller 'visuelle læsefærdigheder' måske ikke helt kan forklares med tekstualiteten som forlæg. ${ }^{13}$ Mest afgørende i den sammenhæng er erkendelsen af, at den billedlige repræsentation ganske vist altid har været problematisk, men nu er blevet mere presserende end nogensinde før på alle kulturelle niveauer, fra de mest sofistikerede filosofiske spekulationer til massemediernes mest vulgære produktioner. De traditionelle inddæmningsstrategier synes ikke længere at være tilstrækkelige, og der forekommer ikke at kunne herske nogen tvivl om behovet for en global kritik af den visuelle kultur.

Den fornyede interesse for Panofskys arbejde er utvivlsomt et symptom på den billedlige vending. Den blotte rækkevidde af Panofskys lærdom, hans evne til at bevæge sig med fuld autoritet fra oldtidens kunst til den moderne og låne provokerende og sigende indsigter fra filosofi, optik, teologi, psykologi og filologi, gør ham til et uomgængeligt forbillede og udgangspunkt for enhver generel redegørelse for det, der i dag går under betegnelsen 'visuel kultur'. Måske mere afgørende er det, at Panofskys tidligere teoretiske arbejder ikke blot er genstand for passiv ærefrygt, men også for nogle ret ophedede kunsthistoriske diskussioner. Er han virkelig "kunsthistoriens Saussure"? Som Giulio Argan på et tidspunkt hævdede. Eller er han blot en "pudsig parentes" i tysk kunsthistories triste, neokantianske "labyrint", som Donald Preziosi har givet udtryk for? Har Panofskys ikonologi drevet det til mere end en "mekanisk kryptografi", der blot gør et af de mest bagstræberiske humanistiske fag endnu mere indskrænket? Eller foregreb han virkelig Foucault, som de begejstrede redaktører fra Zone Books synes at mene, ved at skabe en "'arkæologi' for den vestlige repræsentation, som rækker langt ud over den kunsthistoriske forsknings normale horisont"? ${ }^{14}$

Der er noget rigtigt ved alle disse påstande. Panofsky er bestemt blevet approprieret af alle mulige mere eller mindre latterlige faglige rutiner, man har helt sikkert ikke altid forstået de intellektuelle kontekster for hans tankegang til bunds, hans ikonologi ville utvivlsomt have kunnet vinde meget ved et bekendtskab med 
Mukarovskijs semiologi, og han vil absolut være mere spiselig for samtiden, når Preziosi engang har fået ham "grillet igennem på nietzscheansk grundlag." ${ }^{15}$ Ikke desto mindre er det bemærkelsesværdigt, at hans klassiske essay fra 1924, Die Perspektive als 'symbolische Form', stadig står så stærkt, som det gør - bl.a. i form af en klar og elegant oversættelse med en autoritativ introduktion af Christopher Wood. Dette essay er fortsat et afgørende paradigme for ethvert ambitiøst forsøg på en generel kritik af den billedlige repræsentation. Panofskys store syntetiske forsøg på at skrive rummets, den visuelle perceptions og den billedlige konstruktions historie er aldrig blevet overgået, hverken i sin rækkevidde og horisont eller i sin detaljerede nuancering. Man bliver mindet om, at dette ikke blot er historien om renæssancens opfindelse af perspektivet, men en redegørelse for det billedlige rum fra antikken og helt frem til nutiden med inddragelse af Euklid og Vitruvius i den ene ende og El Lissitsky og Ernst Mach i den anden. Det lykkes faktisk Panofsky at fortælle en flerdimensioneret historie om hele Vestens religiøse, videnskabelige og filosofiske tænkning med omdrejningspunkt om billedet som figur, dvs. som det konkrete symbol for et komplekst kulturelt felt dækkende hvad Foucault ville have kaldt det 'synlige' og det 'artikulerbare'. Ydermere er denne historie funderet på datidens mest avancerede psyko-fysiologiske redegørelser for visuel erfaring. Panofsky påpegede, at renæssanceperspektivet ikke var i overensstemmelse med den egentlige visuelle erfaring, hverken som den blev forstået videnskabeligt i begyndelsen af det 20. århundrede eller intuitivt i det 16. århundrede eller Antikken. Han kalder perspektivet en "principiel abstraktion fra strukturen af det psykofysiologiske rum" ${ }^{\text {"16 }} \mathrm{og}$ anslår en forbindelse mellem "de mest moderne psykologiske indsigter i" den visuelle perception og de billedlige eksperimenter hos Mondrian og Malevich. ${ }^{\text {17 }}$

Det, der forbliver uafklaret i Panofskys perspektiv-essay og i hans ikonologiske metode i det hele taget, er spørgsmålet om beskueren. Panofsky formulerer sig konsekvent tvetydigt omkring det egentlige subjekt i perspektivets historie..$^{18}$ De praksisser og forskrifter, der knytter sig til den billedlige repræsentation, bliver gennemgående ladt ude af betragtning under påstandene om transformationer i "det subjektive synsindtryk" og fraserne om en bestemt "epokes ... anskuelse"19 - som om en historisk epoke kunne være genstand for en visuel perception eller beskrives som perciperende et objekt. Indimellem udtrykker Panofsky sig, som om den visuelle perception har en historie, der kan aflæses direkte i de billedlige konventioner, der udtrykker den i 'symbolske former'. Andre gange behandler han det visuelle som en naturlig, fysiologisk mekanisme, der ligger uden for historien, en mekanisme, som man havde et intuitivt greb om i oldtidens optik og nærmede sig en videnskabelig forståelse af i den moderne psyko-fysiologi. Panofskys filosofiske sprogbrug med termer som 'subjekt' og 'objekt' (i modsætning til for eksempel 'individ' og 'verden' eller 'selv' og 'anden') forværrer blot problemerne yderligere ved at genbruge perspektivets optiske figurer som grundlæggende epistemologiske kategorier. ${ }^{20}$ 'Subjektet' er paradigmatisk en beskuer, hvorimod 'objektet' er et visuelt billede. Syn, rum, verdensbilleder og kunstbilleder sammenvæver ét stort billedtæppe af 'symbolske former', der syntetiserer den enkelte historiske periodes Kunstwollen. Hvis den billedlige vending skal kunne indfri Panofskys ambitioner på vegne af en kritisk 
ikonologi, står det imidlertid klart, at vi er nødt til at optrævle dette billedtæppe og ikke blot brodere videre på det.

Et væsentligt forsøg på at vikle beskuelsens tråd ud af kunsthistoriens herskende overfortælling kan findes i Jonathan Crarys Techniques of the Observer. Af flere årsager vil jeg gerne behandle denne bog lidt mere indgående. For det første er den bevidst situeret i tilknytning til de generelle problemer, der rejses af Panofskys ikonologi, og til de mere specifikke problemer i perspektiv-essayets sammenfletning af spørgsmål om visuel repræsentation og videnskabelige redegørelser for den visuelle perception som en kropslig og mental aktivitet. For det andet positionerer den sig i en kritisk relation til traditionel kunsthistorie ved at insistere på betydningen af en bredere kritik af visuel kultur, der sætter de forskellige beskuer-modeller i centrum. Endelig er der det ved Crarys bog, at den i kraft af nogle af sine begrænsninger og udskejelser faktisk er meget illustrativ for en række kroniske problemer i selve forestillingen om at historisere og teoretisere beskuelsen, idet den viser, hvor svært det reelt er at bryde ud af de hinanden spejlende totaliteter i Panofskys ikonologi. Når jeg fremsætter denne kritik, er det ikke, fordi jeg mener, at jeg dermed har løst alle de problemer, Crary løber ind i, men i samarbejdets ånd som led i en bestræbelse, der forekommer mig endnu at befinde sig i de første, eksplorative stadier.

Crary ønsker at skrive en bog om "synet og dets historiske konstruktion" (s. 1), men han vil samtidig til en vis grad afkoble den historie fra "en redegørelse for diverse forskydninger i de repræsentationelle praksisser". ${ }^{21}$ Ved at omgå, hvad han kalder kunsthistoriens "kernefortælling" - skiftet fra "renæssancens perspektiviske eller normative" synsmodel, indvarslet af den kunstneriske modernisme i 1870'erne og 1880'erne - henleder Crary vores opmærksomhed på tidligere "systemiske forskydninger" i psykologiens, fysiologiens og optikkens diskurser. Det centrale argument i bogen er, at "en ny form for beskuer begyndte at tage form i Europa" i de første årtier af det 19. århundrede. I det 17. og 18. århundrede var beskueren ifølge Crary en legemløs figur, hvis visuelle erfaring var udformet med "det ulegemlige camera obscura" som forbillede. I det 19. århundrede fik denne beskuer en krop. Psykofysiologiske fænomener som efterbilleder erstattede den fysiske optiks paradigmer, og nye optiske apparater som stereoskopet og phenakistoskopet opstod på baggrund af "den radikale abstraktion og rekonstruktion af den optiske erfaring" (s. 9).

Crary anfører en række slående eksempler på forskydningen i den videnskabelige forståelse af visuel erfaring: Typisk for disse er hans diskussion af Goethes lukning af camera obscuraets åbning med henblik på kontemplation af de "fysiologiske" farver, der flyder rundt og forvandler sig i det opståede mørke, og hans skarpe beskrivelse af stereoskopet som en slags overgang mellem teatrets (obskøne) scenerum og "Riemann-rummets" euklidiske fragmenter (s. 126-27). Crary tilbyder også nogle vigtige formaninger om teori og metode. Han advarer mod tendensen til simpelthen at "aflæse" beskueren i de optiske apparaturer (hvilket var kendetegnende for den tidlige filmvidenskab) gennem en slags teknologisk determinisme. Han bemærker, at "en given tekniks position og funktion er historisk variabel" (s. 8), og påpeger, at camera obscuraet ikke nødvendigvis indtager samme position i det 18. århundredes redegørelser for synet som stereoskopet i det 19. århundredes 
fremstillinger af samme emne. Han synes dog først og fremmest at være opmærksom på, at selve "beskuer-begrebet" og tanken om en "synets historie" er forbundet med graverende teoretiske problemer: Måske findes det "19. århundredes beskuer" slet ikke, måske findes der kun "effekten af et irreducibelt heterogent system af diskursive, sociale, teknologiske og institutionelle relationer" (s. 6). Måske er der ikke nogen "sand historie" om dette emne, men kun en retorik, der mobiliserer visse materialer fra fortiden for at udvirke en effekt i nutiden (s. 7).

Crary roder sig imidlertid også ind i nogle af de velkendte faremomenter ved ikonologien, idet han glemmer at overholde mange af sine egne advarsler mod overgeneraliseringer og kategoriske sandhedsfordringer. Hans interessante og i udgangspunktet ganske tilbageholdende fremstilling af optiske apparater og fysiologiske eksperimenter bliver hurtigt blæst op til en storstilet redegørelse for en "gennemgribende transformation af selve den måde, hvorpå man i det hele taget forstod beskueren som figur", en beskrivelse af "de hegemoniske diskurser og praksisser, hvori synet som sådan fandt sted" og en præsentation af "det styrende forlæg for, hvad en beskuer var i det 19. århundrede" (s. 7). Styrende for hvem? Hegemoniske inden for hvilken sfære? Gennemgribende på tværs af hvilke sociale skel? Det er spørgsmål, som Crary ikke kan stille, endsige besvare, da han ikke viser nogen interesse for beskuelsens empiriske historie, for studiet af billedlighed som kulturel praksis i hverdagslivet eller i den iagttagendes eller beskuendes krop som præget af køn, klasse eller etnicitet. "Selvfølgelig," siger han "findes der ikke én 1800-tals beskuer, ikke noget enkelteksempel, der kan lokaliseres empirisk" (s. 7). Første halvdel af sætningen er indlysende sand, anden halvdel er helt og aldeles urigtig, hvis Crary dermed mener, at vi ikke har adgang til eksempler på beskuelsespraksis - dvs. hvad folk yndede at se på, hvordan de beskrev det, de så, og hvordan de forstod synserfaring, det være sig på billeder eller i hverdagslivets visuelle optrin. Crarys skepsis over for eksistensen af 'én 1800-tals beskuer' får ham, stik imod al logik, til at konkludere, at der ikke findes nogen beskuer overhovedet, bortset fra i det 'styrende forlæg', han har ekstraheret af den fysiologiske optik og den optiske teknologi. ${ }^{22}$

Endnu mere besynderlig er den historisk determinerende funktion, der tilskrives denne særdeles specialiserede 'forskydning' i beskuelsespraksisserne. Den forvandlede beskuer, der ét sted beskrives som blot en 'effekt', omtales i næste nu som den grundlæggende årsag til omfattende historiske udviklinger: "1870'ernes og 1880'ernes modernistiske maleri og fotografiets udvikling efter 1839 kan betragtes som senere symptomer på eller konsekvenser af dette helt afgørende systemskifte, som allerede var stærkt fremskredent omkring 1820" (s. 7). Faktisk er det netop, når Crary taler om sådanne 'systemskift', 'kløfter' og 'brud', at han fremstår mest konventionel og virker mest rodfæstet i overleverede forestillinger. Bruddets og diskontinuitetens retorik tvinger Crary til at fremføre argumenter, der forekommer at insistere på historisk partikularitet og modstand mod 'homogenitet' og 'totalitet', men faktisk ender med producere netop det, han ønskede at undgå. Typisk er hans påstand om, at 'lighederne' mellem fotografier og andre, ældre former for billeder kun er tilsyneladende: "Det enorme systemiske brud, som fotografiet indgår i, gør sådanne ligheder uvæsentlige. Fotografiet er en del af et nyt og homogent terræn ... hvori beskueren installeres" (s. 13). 
Vokabularet er hentet hos Foucault, men tendensen til en totaliserende herrefortælling, der gennemskærer alle strata og udlader sin kraft over "en enkelt, samlet social overflade", lyder mere som den tyske, idealistiske historie, der er styrende for Panofskys perspektiv-essay - og det var netop den slags, Foucault forsøgte at komme hinsides. Gennem et helt utroligt baglæns historisk bukkespring viser det sig imidlertid, at Crarys Foucault faktisk har påvirket Panofskys vigtigste filosofiske inspirationskilde: "Ernst Cassirers læsning af Oplysningen er ganske vist gået af mode, men den rummer faktisk overordentlig stærke genklange af visse dele af Foucaults konstruktion af 'klassisk tænkning"' (s. 56). Det er meget sigende, at den terminologi, hvormed Crary indledningsvist situerer sin egen historiske position - "midt i en transformation af selve det visuelles væsen, som formentlig er endnu mere gennemgribende end det brud, der adskiller det middelalderlige billedsprog fra renæssancens perspektiv" (s. 1) - er hentet i Panofskys perspektiv-essay. Det er også meget sigende, at han for at finde en støttende analogi til sin "systemiske forskydning" må gribe til M.H. Abrams The Mirror and the Lamp, som er en decideret idealistisk litteraturhistorie over engelsk og tysk romantik, der gennemgående betragtes som et vigtigt museumsstykke - som en historisk fremstilling, der skal kritiseres og omskrives, men ikke anføres som bekræftende autoritet. Det går helt galt, når Crary begynder at beskrive det 18. århundredes camera obscura-beskuer ud fra kategorier som "objektivitet" og "undertrykkelse af subjektivitet" og (ikke overraskende) karakteriserer det 19. århundredes beskuer som hæmningsløst subjektiv (s. 9). Disse præfabrikerede binære subjekt/objekt-oppositioner bringer os med andre ord frem til den gammelkendte historie om "abstraktionen" af den visuelle erfaring fra den "menneskelige beskuer", hvis syn i stigende grad "fremmedgøres" og "tingsliggøres" (s. 11). Det sikreste tegn på, at vi igen er slået ind på en fortærsket, idealistisk historieskrivning, er bogens opsugning af alle mulige forskellige teorier og historier om beskueren i én samlet, ensporet, ikke-empirisk fremstilling af en rent hypotetisk beskuer. Foucault, Adorno, Baudrillard, Benjamin, Debord, Deleuze og andre kritikere indgår alle i lykkelig sameksistens i konstruktionen af denne spejlingshistorie - deres indbyrdes uoverensstemmelser og uenigheder forsvinder i det altoverstrålende lys udgående fra et 'dominerende forlæg', der oplyser et 'homogent terræn'.

Det skal siges til Crarys forsvar, at det er langt sværere at slippe fri af de idealistiske fremstillinger af den visuelle kulturs historie, end man lige skulle tro, og det er i øvrigt heller ikke hævet over enhver tvivl, at Foucault selv undgik de idealistiske forlokkelser. Enhver interessant teoretisk refleksion over visuel kultur må nødvendigvis gennemarbejde sin egen historicitet, og det vil igen indebære en vis abstraktion og generalisering omkring beskuere og visuelle regimer. Ydermere er der på en række vigtige punkter noget både tilfredsstillende og givtigt ved disse overgeneraliserede herre-fortællinger, især når de fortælles af så mesterlig en herre som Panofsky, der vidste mere om den visuelle kulturs historie end Crary og mig og adskillige andre til sammen. Panofskys historie virker stadig så frisk og udfordrende, fordi den er så flerdimensionel, så komprimeret i sin fremførelse og så kompleks i sin spændvidde. Den dækker fire distinkte epoker (oldtiden, middelalderen, renæssancen og moderne tid) under inddragelse af så forskellige diskurser som religion, filosofi, videnskab, psykologi, fysiologi og naturligvis kunsthistorie. Målet er intet 
mindre end en kritisk ikonologi, en teoretisk selvrefleksiv redegørelse for visuel kultur som sådan.

Det ville altså ikke være fair at sammenligne Crarys bog og dens historiske fremstilling i to trin (romantisk/modernistisk) med Panofskys epos om billedmediet og den visuelle kultur. Det ville være en urimeligt høj standard at sætte. Men det er også en standard, vi er nødt til at forholde os til, hvis vi ønsker at udvikle en kritisk kunsthistorie eller nå frem til en forståelse af samtidens visuelle kultur. Kunne det tænkes, at ikonologien, som Christopher Wood synes at mene, "i sidste ende ikke har været en særlig anvendelig kulturhermeneutik", netop fordi dens genstand (det visuelle billede) indfanger dens diskurs og metode i en række tautologiske 'ligheder' mellem visuelle billeder og historiske totaliteter? Er ikonologien - i modsætning til sin metodologisk 'sønderdelende' fætter, filologien - ude af stand til at registrere kulturens brudlinjer, repræsentationens frakturer og beskuernes modstand? Crary har helt sikkert ret, når han udpeger historiseringen af synet og beskuelsen som den helt store gåde for en kritisk ikonologi. Og der kan trods alt også være noget om det, når han siger, at vi står "midt i en transformation af selve det visuelles væsen, som formentlig er endnu mere gennemgribende end det brud, der adskiller det middelalderlige billedsprog fra renæssancens perspektiv". Det er imidlertid ikke det, hans bog handler om (Techniques of the Observer er kun en 'forhistorie' til samtidens billedkultur), og han argumenterer da heller ikke for det, bortset fra at han hævder, at "computer-genereret billedmateriale ... forflytter synet til et plan, der er helt afskåret fra en menneskelig beskuer" (s. 1). Eftersom denne 'forflytning' og afskæring af synet fra det 'menneskelige' i Crarys redegørelse har gjort sig gældende siden 1820, og eftersom denne påpegning skal forestille at være en genklang af Panofskys fortælling om renæssanceperspektivets 'rationalisering af det visuelle billede', er det svært at få øje på den helt store nyhedsværdi i det.

På den anden side er det ikke så forfærdelig forskelligt fra den paradoksale fortælling, jeg selv implicit opererer med, når jeg lokaliserer en 'billedlig vending' i samtidens tænkning og kultur, som genopfører de mest arkaiske billedbekæmpelser på den globale visuelle kulturs elektroniske skærme. Crarys teknologiske symptomer på denne vending - computer-aided design, syntetisk holografi, flysimulatorer, computeranimationer, robotters billedgenkendelse, strålesporing, overfladeskanning, bevægelsesstyring, hjelmbårne virtuelle miljøer, billeddannelse gennem magnetisk resonans og multi-spektrale sensorer - er måske ikke akkurat udtryk for en afskæring af synet fra 'det menneskelige', men der er ingen tvivl om, at disse ting ændrer vilkårene for, hvordan det menneskelige syn kommer til udtryk, og man kan sagtens forstå den moralske/politiske ængstelighed, der ligger i Crarys nostalgiske påkaldelse af det 'menneskelige'. Crarys liste over cyber-visuelle teknologier lyder som et katalog over de forskellige special effects i Arnold Schwarzeneggers Predator eller Terminator eller som en samlet opgørelse over de teknikker, der muliggjorde et spektakulært optrin som Operation Desert Storm. Viden/magt-kvotienten i samtidens visuelle kultur, i de ikke-diskursive repræsentationsregimer, er så massiv, så dybt indlejret i begærets, magtens og voldens teknologier og så gennemsyret af neofascistiske tendenser og global erhvervskultur, at vi ikke kan sidde den overhørig. Den billedlige vending er ikke svaret på noget som helst. Den er blot en måde at stille spørgsmålet på. 
Det er langt fra sikkert, at det er en revideret version af Panofskys ikonologi, der er det bedste svar på spørgsmålet. Problemet er allerede kimlagt i de etymologiske rødder af selve ordet 'ikonologi'. På den ene side stilles vi en diskursiv billedvidenskab i udsyn - logos bemestrer ikonet. På den anden side er der (som Wood påpeger) visse vedholdende billeder og visuelle ligheder, der lister sig ind i den diskurs og fører den frem til totaliserende 'verdensbilleder' og 'verdensanskuelser'. Ikonet i ikonologien er som en fortrængt erindring, der bliver ved at dukke op som et ustyrligt symptom.

Dette problem kan blandt andet håndteres ved at opgive forestillingen om et metasprog eller en metadiskurs for billedforståelsen og i stedet udforske, hvordan billederne forsøger at fremstille sig selv - en 'ikonografi', altså, af en noget anden karakter end den traditionelle. I den forbindelse vil jeg gerne henlede opmærksomheden på to af grundantagelserne i min Iconology. Den første er, at det afgørende skridt under ikonologiens rekonstruktion er at give afkald på håbet om en videnskabelig teori og i stedet iscenesætte sammenstødet mellem 'ikon' og 'logos' i stil med maleriets og litteraturens paragone og traditionen for søster-kunstarter. Dette skridt bringer efter min mening ikonologien langt ud over det komparative studium af verbal og visuel kunst og dybt ind i den grundlæggende konstruktion af det menneskelige subjekt som en væren, der er konstitueret af både sprog og billeddannelse. Nu er der jo selvfølgelig en oldgammel tradition for at betragte sproget som den essentielle menneskelige egenskab: 'Mennesket' er 'det talende dyr'. Billedet er mediet for det undermenneskelige, det vilde, 'umælende' dyr, barnet, kvinden, masserne. Disse associationer er kun alt for velkendte - ligesom i øvrigt den ikke mindre foruroligende modtradition - at 'mennesket' er skabt i Guds billede. Et af de grundlæggende argumenter i Iconology var, at selve betegnelsen for denne 'billedvidenskab' bærer arrene efter et oldgammelt skisma og et fundamentalt paradoks, som altid vil præge dens funktionsmåde.

Det andet afgørende led i genoplivelsen af ikonologien er en gensidigt kritisk konfrontation med ideologiens diskurs. ${ }^{23}$ Jeg forsøgte at arrangere en sådan konfrontation i sidste kapitel af Iconology ved at gennemarbejde de konstitutive figurer (camera obscura og fetich) i Marx' redegørelse for ideologi og handelsvare. Nu vil jeg udvide den diskussion ved at flytte fokus fra ideologiens 'apparatur' (især dens optiske sammenstillingsfigurer) til dens teater-figurer, som jeg (i forlængelse af Geoffrey Hartman) vil kalde "kritikkens genkendelsesscene". ${ }^{24}$

Panofsky opridser 'ur-scenen' for sin egen ikonologiske videnskab i introduktions-essayet i sin Studies in Iconology: "Når en bekendt hilser på mig på gaden ved at tage hatten af, er det, jeg ser fra et formelt synspunkt, kun en ændring i visse detaljer hos en del af den totale struktur af farve, linje og masse, der udgør min synsverden." ${ }^{25}$ Panofskys efterfølgende udfoldelse af denne scene som et hierarki af stadig mere komplekse og sofistikerede perceptioner er kendt stof for alle kunsthistorikere: Den 'formelle' perception viger for (eller bliver "overskredet" af) et "indholds- og meningsområde", den "faktiske" identificering af det formelle mønster som et "objekt (en herre)" - dvs. som noget, der har et navn. Dette plan af "naturlig" eller "praktisk erfaring" forbinder Panofsky antropologisk med vilde (den australske buskmand), og den viger for sit vedkommende for et sekundært plan af 
"konventionel mening" eller betydning. "Det at jeg forstår, at det at tage hatten af, betyder en hilsen, hører imidlertid til et helt andet fortolkningsområde." Endelig når den høflige hilsen op på det globale, kulturelle symbols plan: "Ud over at [udgøre] en naturlig begivenhed i rum og tid, ud over at angive sindsstemninger eller følelser på naturlig måde, ud over at være udtryk for en konventionel hilsen kan min bekendts handling for en erfaren iagttager afsløre alt, hvad der er med til opbygge hans 'personlighed"' - en læsning, der opfatter denne gestus som symptomatisk for en bestemt filosofi og en særlig "national, social og uddannelsesmæssig baggrund".

Disse fire termer - form, motiv, billede og symbol - overlapper hinanden, så de tilsammen danner en tredimensionel fortolkningsmodel, der bevæger sig fra en "præ-ikonografisk beskrivelse" af det "primære eller naturlige indhold" over en "ikonografisk analyse" af "sekundært eller konventionelt indhold" og en "ikonografisk fortolkning" af det "egentlige indhold" og "den (ikonologiske) verden af 'symbolske' værdier" (s. 28-29). Bevægelsen går fra overflade til dybde, fra sanseindtryk til ideer, fra de umiddelbare partikulariteter til en indsigt $\mathrm{i}$, "hvordan den menneskelige forstands væsentlige tilbøjeligheder under forskellige historiske betingelser udtrykkes i bestemte temaer og begreber" (s. 37, Panofskys kursivering).

Der er grunde nok til at godtage hilse-scenen som et naturligt udgangspunkt for en forklaring af maleriets væsen. Det tavse, visuelle møde, den gestus at løfte på hatten og selve 'gestikken' som motiv kan måske virke nærmest uomgængeligt som et grundeksempel, fordi det fanger et af de centrale træk ved det vestlige maleris historie, nemlig det menneskelige kropssprog som vehikel for narrativ, dramatisk og allegorisk betydningsdannelse. Går man lidt længere frem i tiden, vil også Michael Frieds redegørelser for gestik i modernistisk maleri og skulptur kunne bestyrke en i opfattelsen af Panofskys scene som et naturligt og helt uomgængeligt udgangspunkt. ${ }^{26}$ Men sæt nu, at man modsatte sig denne naturlige uundgåelighed og satte spørgsmålstegn ved selve scenen? Hvad ville man da kunne hæfte sig ved?

For det første er der det banale og lidet interessante ved scenen, et tomt emblem på noget så typisk som 'borgerlig høflighed', den flygtige genkendelse blandt subjekter, der er indbyrdes uinteresserede i hinanden, der ikke siger noget til hinanden og blot fortsætter med deres respektive forehavender. Eksemplet er selvfølgelig ligegyldigt i sig selv, det eksemplificerer netop, iscenesætter, ja udstiller nærmest sin egen uvæsentlighed og manglende betydning. Det har ikke fortjent skarp granskning eller hård bedømmelse. Det er ikke værdigt nok til at være genstand for et maleri - det danner ikke ramme om nogen stor historisk begivenhed, et epos eller en allegori. Det har ingen anden funktion end at eksemplificere de minimale egenskaber ved visuel kommunikation og repræsentation - det etablerer en grundlinje, hvorudfra man kan måle vigtigere og mere komplekse former for visuel repræsentation.

For det andet er der transformationen af dette simple, sociale møde (de to mænd, der passerer forbi hinanden på gaden) til et møde mellem et subjekt og et objekt (perceptionen og 'læsningen' af et billede, et maleri) og i sidste ende til et møde mellem to 'genstande' for repræsentation (de to forbipasserende skikkelser eller herrer, der sættes i scene for os her i Panofskys egen 'teoretiske scene'). "Overfører vi resultatet af denne analyse fra dagliglivet til et kunstværk, kan vi finde de samme tre lag i dets indhold eller mening" (s. 27) - former som objekter, objekter 
som billeder og billeder som symboler. Panofsky, der hilser på en bekendt på gaden, bliver en figuration af hans møde med det enkelte maleri: Den 'scene', hvor ikonologen hilser på ikonet, blev paradigmet for en ikonologisk videnskab.

For det tredje er der konstruktionen af en hierarkisk struktur, indsat som narrativ overgang fra simpelt til komplekst, fra trivielt til vigtigt, fra naturligt til konventionelt, fra praktisk til litterær eller filosofisk viden, fra analytisk til syntetisk tolkning, fra primitiv, vild konfrontation til civiliseret, intersubjektivt møde. De første stadier er "rent automatiske" (s. 26), de senere stadier er refleksive, velovervejede. I vores manglende evne til erkende indholdet i et maleri "er vi alle australske buskmænd" (s. 33).

For det fjerde er der modstillingen mellem 'ikonografi' og 'ikonologi', opstrenget som en omvendt fortælling, hvor de højere niveauer går forud for de lavere i et styringshierarki. "Derfor måtte vor praktiske erfaring kontrolleres af en indsigt i, hvordan objekter og begivenheder under forskellige historiske forhold udtryktes i former" (s. 38), og den kendsgerning, at "vi fatter disse træk i en brøkdel af et sekund og næsten automatisk," må ikke få os til at tro, at vi nogensinde kan give en korrekt præ-ikonografisk beskrivelse af et kunstværk uden at have fattet dets historiske locus så at sige per intuition (s. 33).

For det femte er der privilegeringen af det litterære maleri, hvor det er 'billederne' af den menneskelige krop og dens gebærder, der er betydningsbærende, og marginaliseringen af de ikke-litterære former ("landskabsmaleri, stilleben, genremaleri") som "exceptionelle fænomener, der betegner de senere, overforfinede faser i en lang udvikling". Panofsky kommer ikke ind på abstrakt kunst eller andre former, "hvor hele den sekundære eller konventionelle emnesfære er elimineret" (s. 30). Han kommer ikke ind på de billedtraditioner, der sætter strenge begrænsninger (herunder deciderede forbud) for repræsentationen af den menneskelige skikkelse.

For det sjette er der homogeniseringen af disse oppositioner og hierarkier til en 'organisk helhed' - i form af "den menneskelige forstands væsentlige tilbøjeligheder", som er tilgængelige for ikonologens "syntetiske intuition" (s. 37).

Den blotte opremsning af disse elementer er formentlig nok til at opridse konturerne af en kritik, der ville betvivle homogeniteten af den ikonologiske proces. De højere perceptionsniveauers 'styring' af de lavere vidner umiddelbart om muligheden for modstand: Modernismen lader sig således forstå som en modstand mod netop Panofskys ikonologi og dens romantiske hermeneutik, dens literære-figurale grundlag og dens velkendte opbud af analytisk/syntetiske oppositioner. Panofskys ikonologi er en ikonologi, hvori 'ikonet' er helt igennem opslugt af 'logos' forstået som en retorisk, litterær eller ligefrem (om end knap så overbevisende) videnskabelig diskurs.

Men der er andet og mere på spil her end blot, at Panofskys metode reproducerer det 19. århundredes konventioner eller undergraver sin egen logik gennem det figurative sprog, som det udspiller sig i Panofskys tekst. Vi er for det første nødt til at spørge, hvad der adskiller denne scene, dens ekstrapolation og den tilstræbte ikonologiske 'videnskab', hvorfor denne scene er uheldig i forhold til indfrielsen af den målsætning, og hvilke scener der eventuelt ville kunne være mere befordrende. For det andet er vi nødt til at spørge - hvilket i sidste ende vil føre os tilbage til Panof- 
skys essay om perspektivet - hvad vi kan lære af Panofskys kløgtige valg af mødet på gaden som ur-scene. Hvordan ville en postmoderne ikonologi - eller en kritisk ikonologi, som jeg ville foretrække at kalde den - kunne tage denne scene op igen?

Én ting, som en kritisk ikonologi helt sikkert ville gribe fat i, er ikonets modstand mod logos. Det er nærmest en postmodernistisk kliche, at alt sprog er absorberet i billeder og 'simulacra' i en semiotisk spejlsal. Hvor den traditionelle ikonologi fortrængte billedet som billede, da vil en postmoderne ikonologi udgrænse sproget. Dette er ikke en 'historie', men snarere en kernefortælling, der er indlejret i grammatikken i selve 'ikonologien' som konceptuel fraktur, en sutur af billede og tekst. Det ene må gå forud for det andet, må dominere, modstå, supplere det andet. Billedets og tekstens andethed i forhold til hinanden er ikke kun et spørgsmål om strukturelle analogier, som om billedet blot tilfældigvis var tekstens modstykke. Det drejer sig derimod, som Daniel Tiffany har vist, om selve de termer, hvori andetheden som sådan kommer til udtryk i den fænomenologiske refleksion, især i relationen mellem det talende Selv og den sete Anden. ${ }^{27}$

Det er altså den kritiske ikonologi, der bringer os tilbage til de to mænd, der hilser tavst på hinanden på gaden, den konstitutive figur eller 'teoretiske scene' for den ikonologiske videnskab - det jeg har kaldt "hyper-ikonet". ${ }^{28}$ Det ville være alt for let at gøre denne scene til genstand for en ideologisk analyse (hvilket jeg delvist har gjort her), og behandle den som en allegori over den borgerlige høflighed, der - som Panofsky påpeger - bygger på et residuum af "middelalderens ridderlighed: Bevæbnede mænd plejede at tage hjelmen af for at vise deres fredelige hensigter" (s. 26). Lad os hellere tage en anden scene, en eksplicit ideologisk scene, og i stedet underkaste den en ikonologisk analyse.

Scenen er Althussers beskrivelse af ideologi som en proces, der "interpellerer de konkrete individer som konkrete subjekter". ${ }^{29}$ Ideologi er en "(fejl)-genkendelsesfunktion" (s. 50) eksemplificeret ved adskillige såkaldte "teoretiske scener" (s. 52). Den første scene:

4 For at tage et i høj grad 'konkret' eksempel, så har vi alle venner, der, når de banker på vores dør, og vi gennem den lukkede dør stiller spørgsmålet: 'Hvem er det?', svarer (for 'det er jo klart') 'det er mig'. Og vi genkender faktisk, at 'det er ham' eller 'det er hende'. Vi åbner døren og 'ganske rigtigt: det er hende, som er der.' (s. 51)

Umiddelbart efter denne scene følger en anden, og her rykker vi så ud på gaden:

64 For at tage et andet eksempel: Når vi på gaden genkender én, som vi (gen)kender, så markerer vi over for ham, at vi har genkendt ham (og at vi har genkendt, at han har genkendt os) ved at sige 'goddag kære ven' og ved at trykke ham i hånden (en materiel, rituel praksis i dagliglivets ideologiske genkendelse, i det mindste i Frankrig: andre steder, andre ritualer). (s. 51)

Hvordan skal man 'læse' disse hilse-scener i sammenligning med Panofskys? De er for det første lidt mere detaljerede, lidt mere 'konkrete', som Althusser formulerer det - i anførselstegn. Det sociale møde er ligeledes mere intimt og betydningsfuldt: 
Det er venner og bekendte, mænd og kvinder, der mødes og hilser på hinanden her, og der er ikke blot, som hos Panofsky, tale om envejs høflighedstegn, der lige så godt kunne have udspillet sig mellem anonyme fremmede. Althussers scene er et forspil til et narrativt eller dramatisk møde, en dialog, hvor disse ord danner åbningsreplik. Hans scene sætter parentes om det visuelle og fremhæver den blinde, mundtlige ordveksling - man hilser på hinanden gennem en lukket dør eller råber uset "hov, De der!" til én på gaden - "den mest banale politiinterpellation (eller en anden interpellation) fra hverdagen" (s. 52). Panofskys scene er en rent visuel scene, der udveksles ingen ord, kun gestik, og der er intet, der kunne få os til at forvente, at der skulle udspille sig noget yderligere mellem de forbipasserende. Panofsky letter aldrig selv på hatten, han trækker sig i stedet ind i en dissektion af sin egen perceptuelle og forståelsesmæssige aktivitet - fortolkningen af et objekt i det visuelle/hermeneutiske rum i tre niveauer.

Det drejer sig her om to grundlæggende 'teoretiske scener' for to videnskaber, Panofskys billedvidenskab (ikonologi) og Althussers videnskab om (falsk) bevidsthed (ideologi). Symmetrien er selvfølgelig ikke helt perfekt. Ikonologi er en videnskab, hvorimod ideologi er en teoretisk genstand, ikke en teori, men et negativt symptom, der skal diagnosticeres. Ifølge Panofsky er ikonologien 'diagnostikeren' (s. 37), og de (godartede) 'symptomer' er de kulturelle symboler, han fortolker med sin 'syntetiske intuition' - de teoretiske genstande (andre mennesker, malerier), man støder på i den visuelle genkendelses ur-scene.

Lad os nu opføre en genkendelsesscene (i modsætning til blot en sammenligning) mellem Panofskys ikonologi og Althussers ideologi ved at bede dem hver især genkende og 'hilse' på sig selv i den anden. Ikonologien genkender sig selv som en ideologi, dvs. som et naturaliseringssystem, en homogeniserende diskurs, der udvisker konflikt og forskel med figurer som 'organisk enhed' og 'syntetisk intuition'. Ideologien genkender sig selv som en ikonologi, en formodet videnskab og ikke blot genstanden for en videnskab. Det opdager den lettest simpelthen ved at gen-kende og aner-kende sin (etymologiske og historiske) oprindelse som en 'videnskab om ideer', hvor 'ideer' forstås som billeder - den 'videnskab', der blev udviklet af Destutt de Tracy og Den Franske Revolutions oprindelige 'ideologer'. ${ }^{30}$

Pointen med denne gensidige genkendelse er altså ikke blot at gøre ikonologien 'ideologisk bevidst' eller selvkritisk, men også at gøre den ideologiske kritik ikonologisk bevidst. Den ideologiske kritik kan ikke bare appliceres på diskussionen af billedet, eller tekst/billede-forskellen, som en slags over-metode. I kraft af sin intervention bliver den selv underkastet intervention fra genstandens side. Det er derfor, jeg har kaldt denne forestilling om ikonologien kritisk og dialektisk. Det er ikke noget, der ligger i en eller anden overordnet kode, en ultimativ horisont af Historie, Sprog, Menneskelig Bevidsthed, Væren eller noget andet abstrakt princip. Det er noget, der fører os tilbage til åstedet, til ur-scenen, hvor de to Subjekter hilser på hinanden - hvor det talende Subjekt og det seende Subjekt mødes, ideologen og ikonologen.

Det, vi kan lære af dette møde, er, at videnskabens store forlokkelse, forstået som den panoptiske overvågning og beherskelse af objektet/den 'Anden' (det være sig en person eller et billede) er den 'forbrydelse', der ligger indlejret i disse scener. 
Den bliver ikke direkte opført for os: Figurerne udøver kun mere eller mindre konventionelle sociale hilseformer. For at kunne 'se' forbrydelsen må vi undersøge selve scenen, syns- og genkendelsesfeltet, som danner grundlag for, at figurerne overhovedet kan optræde.

Det er netop denne tomme scene, det grundlæggende billede for enhver tænkelig visuel-spatiel kultur, Panofsky præsenterer i sit perspektiv-essay. Denne tekst fremfører, som Michael Podro har gjort opmærksom på, et (selvmodsigende) dobbeltargument om renæssanceperspektivet. For det første, at det "ikke besidder nogen unik autoritet som organisering af afbildningen af spatielle relationer, at det blot er led i en specifik kultur og har samme status som andre former for spatiel fremstilling i andre kulturer". For det andet, at det "udgør et absolut udsigtspunkt, hvorfra man kan fortolke andre konstruktioner". ${ }^{\text {i }}$ Perspektivet er en figuration af det, man ville kalde ideologi - en historisk, kulturel formation, der udgiver sig for at være en universel, naturlig kode. Det "homogene, uendelige rums" kontinuum (s. 187) og den bipolære reduktion til et enkelt udsigts- eller forsvindingspunkt i den henholdsvis 'subjektive' og 'objektive' ende af det visuelle/billedlige rum udgør den struktur eller de rammer, hvori Panofskys treleddede ikonologi giver mening. Perspektivet er således på én gang blot et symptom og den diagnostiske syntese, der gør fortolkningen videnskabelig og symptomerne forståelige. ${ }^{32}$ Panofsky er tæt på at sige dette eksplicit i sine afsluttende bemærkninger i "Ikonografi og ikonologi”:

46 Ligesom det var umuligt for middelalderen at udforme det moderne perspektivsystem, der er baseret på forståelse af en fast afstand mellem øjet og objektet og således sætter kunsten i stand til at opbygge omfattende og konsistente billeder af synlige ting; lige så umuligt var det at udtænke den moderne idehistorie, der er baseret på forståelse af en intellektuel afstand mellem nutiden og fortiden og således sætter videnskabsmanden i stand til at opbygge omfattende og konsistente begreber om forgangne perioder. (s. 51)

Panofskys ikonologi forholder sig til perspektivet som et historisk/teoretisk objekt blandt andre sådanne, men samtidig betragter den selve 'den moderne idehistorie' som modelleret efter perspektivsystemet. Den billedlige repræsentations historie viser sig kun at være forståelig inden for rammerne af et teoretisk billede, der skal forstille selv at 'indgå i' den historie.

Det tilsvarende stadie i Althussers ideologitænkning afslører sig, når han går over til "enhver ideologis formelle struktur", som han forsikrer os, "altid er den samme" (s. 55). Althussers eksempel på ideologiens universelle struktur er den kristne religions ideologi (som han hævder ville kunne erstattes af enhver anden "moralsk, juridisk, politisk, æstetisk osv." ideologi). Specifikt griber han fat i den teologiske henvendelse eller "interpellationen af individerne som subjekter" gennem "et Andet Subjekt, som er Unikt og centralt" (s. 57), nemlig Gud. Den relation, der etableres gennem denne henvendelse, er kendetegnet ved spejling og undertvingelse eller dominans: "Gud er altså Subjektet, og Moses og de utallige subjekter i Guds folk dets interpellerede samtalepartnere: dets spejle, dets spejlbilleder. Er menneskene ikke blevet skabt i Guds billede?" (s. 57). Det stadie, hvor den ideologiske henvendelse til individerne udfolder sig, minder altså om en slags spejlsal: 
64 Vi konstaterer, at strukturen i enhver ideologi, idet den interpellerer individerne som subjekter i et Unikt og Absolut Subjekts Navn, er spejlmæssig, dvs. er som et spejl, og spejlmæssig i dobbelt forstand: Denne Spejlmæssige fordobling er konstitutiv for ideologien og sikrer dens funktion. Hvad der betyder, at enhver ideologi er centreret, at det Absolutte Subjekt indtager pladsen i centrum og omkring sig interpellerer den uendelige mængde af individer som subjekter i en dobbelt spejlrelation, således at den underkaster subjekterne under Subjektet, samtidig med at den i Subjektet, hvor ethvert subjekt kan betragte sit eget ... billede, giver dem garantien for, at det faktisk er dem, og faktisk er Ham, som det drejer sig om. (s. 58)

Det hører med, at det er her, Althussers ideologiske 'scener' viger for muligheden for en 'videnskab', en generel redegørelse for 'enhver ideologis formelle struktur'. Det er dog svært at komme uden om det ironiske i, at en videnskabelig teori om ideologi således funderes på en model, der er hentet i teologien. Althusser står ganske vist uden for denne model: Han ser den på afstand og sætter den, som Panofsky ville have sagt, i perspektiv for os. Hvis vi kan se, at ideologi er en spejlsal, kan vi måske smadre spejlene og redde de undertrykte subjekter fra det almægtige Subjekt? Eller kan vi det? Er denne ideologiens 'formelle struktur' i lighed med Panofskys 'perspektiv' en specifik historisk formation, som vil forsvinde igen, når produktionsog reproduktionsrelationerne og de deraf afledte sociale relationer transformeres? Eller er den (igen i lighed med Panofskys 'perspektiv') en universal, naturlig struktur, der absorberer alle sociale former og historiske epoker? Hvis Althusser vælger den første mulighed (at modellen er en specifik historisk formation), må han give afkald på videnskabelighed og universalitet - den kristne ideologi vil i så fald ikke nødvendigvis kunne 'erstattes af enhver anden moralsk, juridisk, politisk, æstetisk osv. ideologi'. Dette 'osv.' kunne måske dække over formationer, der adskiller sig markant fra den religiøse ideologi, som for sit vedkommende måske er historisk og kulturelt betinget. Hvis Althusser derimod vælger den anden mulighed og fastholder spejlmodellens universalitet og videnskabelighed, ender han, i lighed med Panofsky, som en ikonolog, der har en ideologi uden at vide det.

Hvordan kan vi opføre et møde mellem Panofsky og Althusser, der er andet og mere end blot et dødt punkt mellem videnskab og historie, en fatal spejling af ideologi og ikonologi? Hvad kan den franske marxistiske filosof og den tyske kantianske kunsthistoriker gøre for hinanden - ud over at lette på hatten, når de træffer hinanden på gaden? Kan de 'hilse' på hinanden eller 'henvende' sig til hinanden fra hver sin side af en lukket dør, som i Althussers dramatisering, og forvente nogen anden genkendelse, nogen anden vedkendelse, end den 'banale' fejlreaktion, når nogen råber 'Hov, De dér'?

Måske ikke - medmindre vi kortlægger det fællesrum, de indtager, som slet og ret er det forhold, at de begge centrerer deres overvejelser om en genkendelsesscene. Det væsentligste ved genkendelsen som kobling mellem ideologi og ikonologi er, at det forskyder begge 'videnskaber' fra et epistemologisk, 'kognitivt' terræn (subjekters viden om objekter) til et etisk, politisk og hermeneutisk terræn (subjekters viden om subjekter, måske ligefrem Subjekters viden om Subjekter). Vurderingskriterierne skifter fra er-kendelse til gen-kendelse, fra epistemologiske videnskatego- 
rier til sociale kategorier som 'anerkendelse'. Althusser påminder om, at Panofskys forhold til billeder begynder med et socialt møde med en Anden, og at ikonologien er en videnskab, der går ud på at indoptage denne Anden i et homogent, enhedspræget 'perspektiv'. Panofsky påminder os om, at Althussers lokale udtryk for ideologi, et subjekts henvendelse til et andet subjekt (s/s), alle er iscenesat i en spejlsal konstrueret af det suveræne Subjekt (S/s), og at den ideologiske kritik risikerer at ende som blot endnu en ikonologi. Disse påmindelser løser ikke problemet for os, men de kan måske gøre det lettere for os at genkende det, når vi ser det.

På dansk ved Morten Visby. Oprindelig trykt i Artforum, marts 1992.

(C) W.J.T. Mitchell og Artforum.

\section{Noter}

I Richard Rorty, Philosophy and the Mirror of Nature (Princeton: Princeton University Press 1979), s. 263. Jf. den tidligere essaysamling redigeret af Rorty, The Linguistic Turn: Recent Essays in Philosophical Method (Chicago: University of Chicago Press 1967).

2 En anden vigtig udviklingslinje er Stanley Cavells fors $\emptyset$ g, i The World Viewed: Reflections on the Ontology of Film (Cambridge, MA: Harvard University Press 1980), på at sætte amerikansk film og moderne maleri i tale inden for den anglo-amerikanske romantiks filosofiske rammer.

3 Her læner jeg mig op ad analysen af Foucaults metode i Gilles Deleuze, Foucault (Paris: Éditions de Minuit 1986). Jf. især kapitlet om "Les strates ou formations historiques: le visible et l'énonçable (Savoir)". Hvad angår forestillingen om et 'skopisk regime', jf. Martin Jays "Scopic regimes of Modernity" i Vision and Visuality, red. Hal Foster (Seattle: Bay Press 1988), s. 3-27. Jean-François Lyotard, Discourse/Figure (Paris: Klincksieck 1971).

4 Ludwig Wittgenstein, Filosofiske undersøgelser, oversat af Jes Adolphsen og Lennart Nørreklit (København: Munksgaard 1994), s. 84. En mere uddybende redegørelse kan findes i mit essay "Wittgenstein's Imagery and What It Tells Us", New Literary History 19:2 (Winter 1988): 361-70.

5 Rorty, Mirror of Nature, s. 371.

6 Charles Altieri har givet udtryk for, at 'ængsteligheden' her ligger i Wittgensteins opdagelse af, at "den analytiske filosofi i sig selv var baseret på en radikalt billedlig forestilling om selvevidens og repræsentabilitet.” Korrespondance med forfatteren, oktober 1992.

7 Det tætteste, man kommer på en filosofisk syntese af Rorty og Frankfurterskolen, er sjovt nok Martin Heideggers "Die Zeit des Weltbildes" [da. Verdensbilledets tid, oversat af Claus Esmann Andersen, Henrik Borup Nielsen, Mads P. Sørensen, Idéhistoriske arbejdspapirer 1 (Århus: Institut for Idéhistorie, Aarhus Universitet 1996)].

8 Damisch bemærkede for næsten 20 år siden, at kunsthistorien "efter Riegl, Dvorak, Wölfflin og andres storhedstid har været fuldstændig ude af stand til metodologisk fornyelse og frem for alt overhovedet ikke har formået at tage højde for de potentielle bidrag fra de mest avancerede forskningsbestræbelser.” Den første af de avancerede 'forskningsbestræbelser', som Damisch nævner, er lingvistikken. Jf. "Semiotics and Iconography" i The Tell-Tale Sign, redigeret af Thomas Sebeok (Peter de Ridder Press 1975), s. 29.

9 I den forstand har Bryson gjort for angloamerikansk kunsthistorie, hvad Jonathan Culler gjorde for anglo-amerikansk litteraturhistorie omkring ti år tidligere. Jeg vil dog gerne understrege, at 
jeg her tænker på den institutionelle og akademiske side af de seneste udviklinger i amerikansk kunsthistorie. I bredere perspektiv måtte man også inddrage banebrydende anglo-amerikanske forskere som Svetlana Alpers, Michael Baxendall, Rosalind Krauss, Ronald Paulson og Leo Steinberg (som ofte har fået en blandet modtagelse i den akademiske verden). Jeg vil også gerne nævne det vidtrækkende og indflydelsesrige arbejde, der gennem årene er udgået fra T.J. Clark og Michael Fried, som på hver sin måde har været med til at sætte kunsthistoriens teoretiske sprog under intensivt pres lige siden 1960'erne og begyndelsen af 1970'erne.

Io En autoritativ gennemgang af disse tendenser kan findes i Mieke Bal \& Norman Bryson, "Semiotics and Art History", Art Bulletin 73:2 (June 1991): 174-208. Bal og Bryson indvender, at semiotikken overskrider den sproglige vending i sin bestræbelse på at nå frem til en "tværfaglig teori", der kan "holde sig fri af den forudindtagethed, der følger af privilegeringen af sproget" $i$ redegørelser for den visuelle kultur: "Frem for en sproglig vending vil vi foreslå kunsthistorien en semiotisk vending" (s. 175). Jeg tvivler på, at det vil være muligt at etablere en tværfaglig teori, som kan undgå 'forudindtagethed' og opnå neutralitet i repræsentationens metasprog. Jeg har stor respekt for semiotikkens bedrifter og trækker selv ofte på den, men jeg er overbevist om, at den bedste terminologi til beskrivelsen af repræsentationer, de være sig kunstneriske eller ej, skal findes i de repræsentationelle praksissers egen immanente sprogbrug. Der vil selvfølgelig være tilfælde, hvor semiotikkens sprog krydser denne sprogbrug (tænk blot på den stærkt ladede forestilling om et 'ikon'). Sådanne skæringspunkter er imidlertid blot med til at understrege, at semiotikkens tekniske metasprog ikke tilbyder os et videnskabeligt, tværfagligt eller fordomsfrit vokabular, men kun et væld af nye figurer eller teoretiske billeder, der i sig selv kræver fortolkning.

II Yderligere diskussion af de traditionelle versioner af denne frygt kan findes i min Iconology (Chicago: Chicago University Press 1986) og i David Freedbergs The Power of Images: Studies in the History and Theory of Response (Chicago: Chicago University Press 1989).

I2 Mere herom i Kapitel 13, "From CNN to JFK" i min Picture Theory: Essays on Verbal and Visual Representation (Chicago: Chicago University Pres 1995).

I3 Denne negative version af den billedlige vending lå allerede latent i den indsigt, at en semiotik konstrueret med det sproglige tegn som forlæg måske ikke var dækkende for ikonet, et tegn baseret på visuel lighed, netop fordi ikonet (som Damisch pointerer) "ikke nødvendigvis er et tegn" (Sebeok, Tell-Tale Sign, s. 35).

I4 Citeret fra smudsomslaget af Zone Books-udgaven af Erwin Panofskys Perspective as Symbolic Form, red. Sanford Kwinter, oversat af Christopher S. Wood (Cambridge, MA: Zone Books 1991), efterfølgende sidehenvisninger vil gælde den tyske originalversion. Jf. Argan i The Language of Images, red. W.J.T. Mitchell (Chicago: Chicago University Pres 1980) og Donald Preziosi, Rethinking Art History: Meditations on a Coy Science (New Haven, CT: Yale University Press 1989), s. 112. Preziosis bredside i denne bog mod Michael Ann Hollys Panofsky and the Foundations of Art History (Ithaca, NY: Cornell University Press 1984) blev startskuddet til den aktuelle kontrovers om Panofsky.

I5 Jf. Preziosi, Rethinking Art History, s. 121.

I6 Erwin Panofsky, "Die Perspektive als 'symbolische Form"' i Aufsätze zur Grundfragen der Kunstwissenschaft, udgivet af Hariolf Oberer \& Egon Verheyen (Berlin: Volker Spiess 1980), s. 101.

I7 Ibid., s. 166.

I8 Den bedste kritik af Panofskys argumentation i perspektiv-essayet er Joel Snyders "Picturing Vision" i Mitchell, The Language of Images. 
I9 Panofsky, "Die Perspektive als 'symbolische Form”, s. 104.

20 Det er i den forstand, at jeg i tråd med Michael Podro har indvendt, at Panofsky - på et helt grundlæggende niveau af diskursiv figuration - faktisk stadig tror på perspektivets universalitet. Jf. Podros diskussion af korrespondancen mellem Panofskys perspektiv og kantiansk epistemologi i The Critical Historians of Art (New Haven, CT: Yale University Press 1982), s. 188-89 og mit eget essay "Iconology and Ideology: Panofsky, Althusser, and the Scene of Recognition" i Works \& Days 11/12 (Spring/Fall 1988) genoptrykt i Image and Ideology in Modern/Postmodern Discourse, red. David Downing \& Susan Bazargan (Albany, NY: State University of New York Press 1991), s. 321-30. Christopher Woods fremragende introduktion til Panofskys essay rummer også en redegørelse for Panofskys "tvetydigheder" mellem "kunst og verdenssyn", hvor han viser, at "det er perspektivet ... der overhovedet muliggør Weltanschauung-metaforen" (Panofsky, Perspective as Symbolic Form, s. 21, 13).

2I Jonathan Crary, Techniques of the Observer: On Vision and Modernity in the Nineteenth Century (Cambridge, MA: MIT Press 1990), s. 5. De følgende referencer vil være angivet med sidetal direkte i teksten.

22 Crary anfører ganske vist, at der er "synspraksisser", der falder uden for rammerne af hans undersøgelse, men vedbliver at assimilere dem med hans 'styrende forlæg' ved at karakterisere dem som "marginale og lokale former for modstand mod, afbøjning eller forvanskning af de fremherskende synspraksisser" (s. 7). Problemet med den formulering er, at al heterogenitet i den visuelle erfaring på forhånd indpasses i en model baseret af modsætningspar som 'fremherskende/modstand' eller 'universel/lokal', og (endnu mere fundamentalt) at argumentet for Crarys beskuer som et 'styrende forlæg' aldrig rigtig bliver udfoldet. Hans redegørelse for det 19. århundredes beskuer ville helt sikkert have kunnet drage stor nytte af den nyere forskning $\mathrm{i}$ det tidlige biografpublikum, især Charles Mussers History of the American Cinema: The American Screen to 1907 (New York: Macmillan 1990) og Miriam Hansens Babel and Babylon: Spectatorship in American Silent Film (Cambridge, MA: Harvard University Press 1991).

23 Resten af dette essay er hovedsagelig baseret på min artikel "Iconology and Ideology: Panofsky, Althusser, and the Scene of Recognition" (se note 20). Disse sider er oprindelig skrevet som et svar på Tim Erwins meget ansporende kritik af Iconology i særnummeret om "Image and Ideology".

24 Geoffrey Hartman, Criticism in the Wilderness (New Haven, CT: Yale University Pres 1980), s. 253-64.

25 Erwin Panofsky, "Ikonografi og ikonologi" i Billedkunst og billedtolkning. Udvalgte artikler, oversat af Else Mogensen (København: Nyt Nordisk Forlag 1983), s. 26. Jf. Joan Harts diskussion af Panofskys brug af en tilsvarende scene i Karl Mannheims skrifter som forlæg for denne urscene ("Erwin Panofsky and Karl Mannheim: A Dialogue on Interpretation”, Critical Inquiry 19:3 (Spring 1993): 534-66).

26 Jf. Michael Fried, “Art and Objecthood”, ArtForum 5 (Summer 1967): 12-23.

27 Daniel Tiffany, "Cryptesthesia: Visions of the Other", American Journal of Semiotics 6:2/3 (1989): 209-19.

28 Jf. Iconology, s. 5-6, 158.

29 Louis Althusser, Ideologi og ideologiske statsapparater, oversat af Finn Frandsen et al. (Aalborg: Grus 1983), s. 52. Efterfølgende vil sidetallene være angivet direkte i teksten.

30 Jf. min gennemgang af de franske ideologer og ideologiens historie i Iconology, s. 165-66.

3I Podro, The Critical Historians of Art, s. 186. Herefter vil sidetallene blive angivet direkte i teksten. 
32 Joel Snyder maner til forsigtighed på dette punkt, idet han indvender, at Podro "misforstår Panofskys implicitte skelnen mellem indre og ydre." "Malerne," hævder Snyder, "mente, at perspektivet udgjorde et 'absolut standpunkt.' Men set med kunsthistorikerens neokantianske briller i det 20. århundrede har denne forståelse af perspektivet ikke nogen særlig, privilegeret, naturlig status. Panofsky opfatter sidstnævnte som sit eget bidrag til studiet af perspektivet og betragter det indre syn som den fremherskende, uoplyste position" (citeret efter korrespondance med forfatteren). Jeg er enig i, at Panofsky opererer med en sådan skelnen mellem malerens og ikonologens 'perspektiv', men jeg tror samtidig, at Panofskys praksis, valg af eksempler og analysemodel faktisk underminerer denne skelnen. Det er ikke sådan, at Panofsky opfatter det billedlige perspektiv, i bogstavelig forstand, som en universel, ahistorisk norm. Det er snarere et spørgsmål om, at hans model og hele dens figurale og begrebslige udstyr (overflade/dybde, treleddet struktur, 'subjekt/objekt'-paradigmet for relationen mellem beskuer og beskuet) er indlejret i den kantianske epistemologis retorik. 